\title{
Correction to: Liver DNA methylation of FADS2 associates with FADS2 genotype
}

Paula Walle, Ville Männistö², Vanessa Derenji de Mello ${ }^{1}$, Maija Vaittinen ${ }^{1}$, Alexander Perfilyev ${ }^{3}$, Kati Hanhineva', Charlotte Ling ${ }^{3}$ and Jussi Pihlajamäki ${ }^{1,4^{*}}$

\section{Correction to: Clin Epigenetics}

\section{https://doi.org/10.1186/s13148-019-0609-1}

Following publication of the original article [1], the author reported the title of this article has been misspelled. The correct title is "Liver DNA methylation of FADS2 associates with FADS2 genotype".

It has been corrected in the original article as well.

The publisher apologizes for any inconvenience caused by this error.

\footnotetext{
Author details

'Department of Clinical Nutrition, Faculty of Health Sciences, Institute of Public Health and Clinical Nutrition, University of Eastern Finland, 70210 Kuopio, Finland. ${ }^{2}$ Department of Medicine, University of Eastern Finland, Kuopio University Hospital, 70211 Kuopio, Finland. ${ }^{3}$ Epigenetics and Diabetes Unit, Department of Clinical Sciences, Lund University Diabetes Centre, 20502 Malmö, Sweden. ${ }^{4}$ Clinical Nutrition and Obesity Center, Kuopio University Hospital, 70211 Kuopio, Finland.
}

Received: 31 January 2019 Accepted: 31 January 2019

Published online: 12 March 2019

\section{Reference}

1. Walle, et al. Liver DNA methylation of FADS2 associates with FADS2 genotype. Clin Epigenetics. 2019;1 1:10. https//doi.org/10.1186/s13148-019-0609-1.

\footnotetext{
* Correspondence: jussi.pihlajamaki@uef.fi

${ }^{1}$ Department of Clinical Nutrition, Faculty of Health Sciences, Institute of Public Health and Clinical Nutrition, University of Eastern Finland, 70210 Kuopio, Finland

${ }^{4}$ Clinical Nutrition and Obesity Center, Kuopio University Hospital, 70211

Kuopio, Finland

Full list of author information is available at the end of the article
}

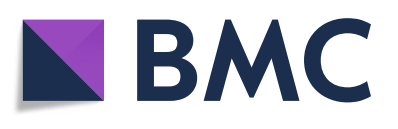

(c) The Author(s). 2019 Open Access This article is distributed under the terms of the Creative Commons Attribution 4.0 International License (http://creativecommons.org/licenses/by/4.0/), which permits unrestricted use, distribution, and reproduction in any medium, provided you give appropriate credit to the original author(s) and the source, provide a link to the Creative Commons license, and indicate if changes were made. The Creative Commons Public Domain Dedication waiver (http://creativecommons.org/publicdomain/zero/1.0/) applies to the data made available in this article, unless otherwise stated. 